\title{
Aphthous Stomatitis Following Ageusia in SARS-CoV-2 Reinfection: A Case Report
}

\author{
Rochman Mujayanto ${ }^{1}$ \\ ${ }^{1}$ Department of Oral Medicine, Faculty of Dentistry, Sultan Agung \\ Islamic University, Semarang, Indonesia
}

Eur J Dent 2021;15:817-819.

\section{Introduction}

Ageusia is one of the probable symptoms of coronavirus disease 2019 (COVID-19). ${ }^{1}$ Complaints of the oral cavity of COVID-19 are still unclear as a manifestation or complication. The authors reported a case of reinfection with severe acute respiratory syndrome coronavirus 2 (SARS-CoV-2) identified as a patient's oral complaint.

\section{Case}

The 35-year-old male patient had a history of moderate symptoms (cough, runny nose, joint pain, muscle pain, and slight shortness of breath), and the SARS-CoV-2 polymerase chain reaction (PCR) result was confirmed positive 50 days ago. The patient received treatment form another hospital, and the SARS-CoV-2 PCR result was negative 24 days later. The patient complained of mouth ulcers, pain to swallow the oral mucosa redness on day 43 and accompanied by ageusia on day 47, and then the patient came to visit an oral medicine specialist. The patient did not complain of any other symptoms, apart from the oral cavity. Body temperature of the patient was $36.7^{\circ} \mathrm{C}$. Extra oral examination revealed multiple vesicles accompanied by yellowish crusts on the vermilion border of the lower lip in the right and left regions. Intraoral examination revealed redness of the oral mucosa, multiple ulcers on the right and left buccal, atrophy of the tongue papillae, and coated tongue on the dorsum of the tongue (-Fig. 1). The patient was suspected of COVID-19 with a differential diagnosis of herpes simplex virus infection. The patient was referred for PCR examination for SARS-CoV-2. The treatment given was methisoprinol $500 \mathrm{mg}$ tablets three times a day and Becom-Zet caplets twice a day for 10 days.

The patient did a swab for PCR examination for SARS-CoV-2 on day 58. The patient hesitated and postponed the SARS-CoV-2 swab examination because the previous PCR result was negative. The PCR examination for
Address for correspondence Rochman Mujayanto, drg, Sp.PM, Department of Oral Medicine, Faculty of Dentistry, Sultan Agung Islamic University, Semarang, Indonesia (e-mail: rochman.mujayanto@unissula.ac.id).

SARS-CoV-2 showed "positive" results with the information E gene 37.69 RdRP 35.45. These results are submitted to a specialist in internal medicine. The treatment given was oseltamivir capsule $75 \mathrm{mg}$ twice a day and Becom-Zet caplet twice a day for 7 days, and the patient was asked to do self-isolation with the health protocol. The patient did another swab for PCR examination on day 68 , with a negative result.

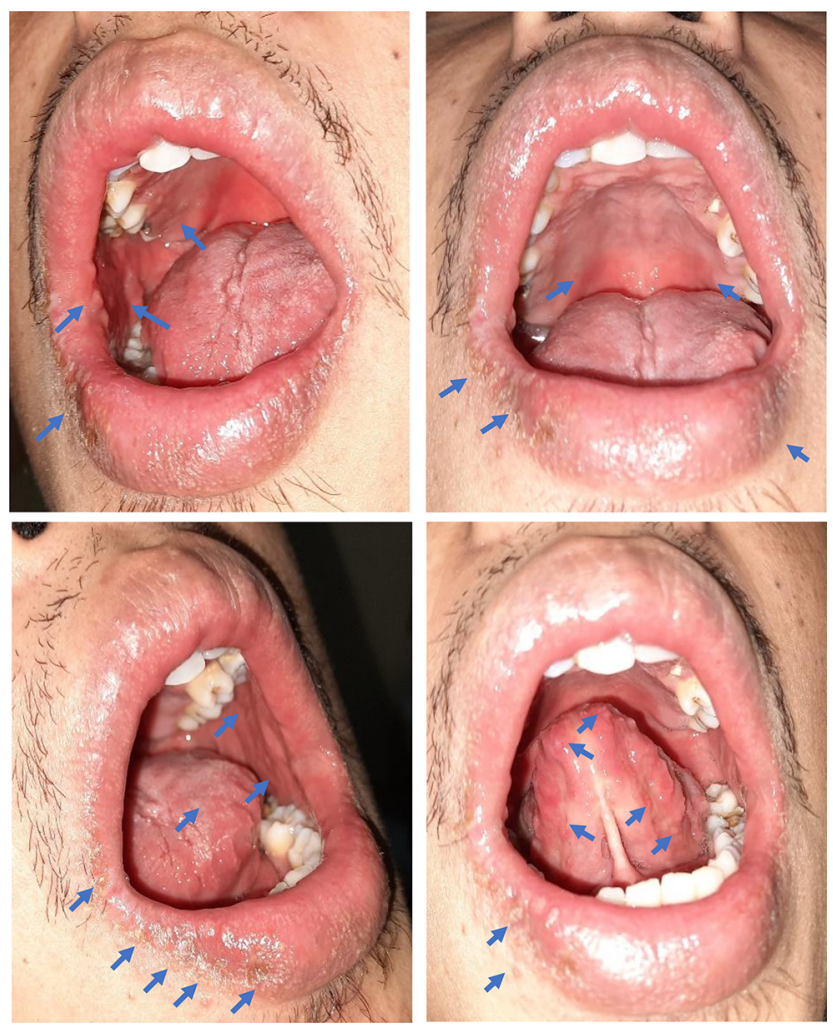

Fig. 1 Intraoral pictures aphthous stomatitis following ageusia in SARS-CoV-2 reinfections. published online

September 27, 2021
DOI https://doi.org/ 10.1055/s-0041-1731927 ISSN 1305-7456
C 2021. European Journal of Dentistry.

This is an open access article published by Thieme under the terms of the Creative Commons Attribution-NonDerivative-NonCommercial-License, permitting copying and reproduction so long as the original work is given appropriate credit. Contents may not be used for commercial purposes, or adapted, remixed, transformed or built upon. (https://creativecommons.org/licenses/by-nc-nd/4.0/).

Thieme Medical and Scientific Publishers Pvt. Ltd. A-12, 2nd Floor, Sector 2, Noida-201301 UP, India 


\section{Discussion}

Oral lesions have not yet been included as an early clinical indicator of COVID-19 patients. However, dentists must be aware of oral lesions that become a differential diagnosis of the clinical picture of COVID-19. ${ }^{2}$ World Health Organization (WHO) has established criteria for COVID-19 cases based on the clinical picture and travel history of patients who are at risk of exposure. The criteria for clinical features are the criteria suspected, probable, and confirmed. ${ }^{1}$

Viral infections that manifest in the oral cavity have prodrome symptoms that mimic those of SARS-CoV-2 infections. ${ }^{3-5}$ These viral infections include herpes simplex virus 1 , varicella zoster virus, coxsackie A virus, and measles virus. The resulting prodromal symptoms are fever, fatigue, headache, myalgia, sore throat, and coryza (specific to measles cases). ${ }^{4}$ Oral herpes manifestations are vesicles in the oral cavity and sometimes also on the upper extremities skin. Herpes labialis manifestations are vesicles at the vermilion border of the lips, Varicella-zoster infection appears as vesicle on the oral mucosa and exanthema on the skin of the upper and lower extremities. Herpes zoster infection manifestations are vesicles blister on unilateral parts of the body. ${ }^{6}$ Herpangina appear as the enanthema of the soft palate and oropharynx. Hand, foot, and mouth syndrome manifestations present as an enanthem of the oral mucosa and exanthema of the palms and soles of the feet. Measles manifestations is an exanthema of the skin of upper and lower extremities, and enanthema of oral mucosa (Koplik spots). ${ }^{7}$ Differential diagnosis of oral manifestations of COVID-19 can be seen in the - Table 1 .

Methisoprinol is an antiviral drug what immunomodulatory activity, by enhancing lymphocyte proliferation, production of cytokine, and natural killer cell cytotoxicity. Methisoprinol for treating the majority of investigated viral infections (herpes simplex virus, human papilloma virus, HIV, cytomegalovirus, Epstein-Barr virus, influenza, and acute respiratory infections). ${ }^{12,13}$ Oseltamivir is a first-line antiviral drug has been recommended by WHO for treatment of COVID-19 patient who are into respiratory. ${ }^{14,15}$

People in high-risk groups for COVID-19 mortality, and at risk of vitamin C deficiency ${ }^{16}$ and Zn deficiency. ${ }^{17}$ Anosmia and ageusia in COVID-19 is due to Zn deficiency to alteration in gustatory or olfactory chemoreceptors. ${ }^{17}$ Vitamin $\mathrm{C}^{16}$ and Zinc ${ }^{18}$ are anti-inflammatory, immunomodulating, and antioxidative stress agents, being considered as prophylactic or adjunct therapy for COVID-19. Vitamin B could potentially prevent or reduce COVID-19 symptoms or treat SARS-CoV-2 infection, by downregulating pro-inflammatory cytokines and inflammation for COVID-19 patients. ${ }^{19}$ Becom-Zet caplets contents vitamin B complex, vitamin C, vitamin E, and Zinc. ${ }^{20}$

\section{Conclusion}

Lesions accompanied by clinical complaints of COVID-19 symptoms need to be investigated for PCR SARS-CoV-2 as gold standard so that further treatment can be given immediately and prevent transmission of SARS-CoV-2.
Table 1 Differential diagnosis of oral diseases based on the World Health Organization COVID-19 case definition

\begin{tabular}{|c|c|c|}
\hline $\begin{array}{l}\text { Criteria } \\
\text { who } \\
\text { COVID-19 } \\
\text { case }^{1}\end{array}$ & $\begin{array}{l}\text { Clinical symptoms } \\
\text { COVID-19 associated } \\
\text { with oral condition }\end{array}$ & $\begin{array}{l}\text { Differential } \\
\text { diagnosis } \\
\text { oral disease }\end{array}$ \\
\hline Suspected & $\begin{array}{l}\text { Three or more acute symp- } \\
\text { toms as follows: } \\
\text { - Fever } \\
\text { - Fatigue } \\
\text { - Myalgia } \\
\text { - Pain throat } \\
\text { - Headache }\end{array}$ & $\begin{array}{l}\text { Oral herpes (primary } \\
\text { or recurrent) } \\
\text { Herpes zoster }^{6,7} \\
\text { Varicella }^{6,7} \\
\text { Herpangina } \\
\text { Hand foot and } \\
\text { mouth diseases } \\
\text { Measles }^{4,6,7}\end{array}$ \\
\hline Probable & Loss of taste (ageusia) & $\begin{array}{l}\text { Side effects of drugs }{ }^{8} \\
\text { Nutritional } \\
\text { deficiencies }^{9} \\
\text { Diabetes mellitus }^{9} \\
\text { Hypotyrodism }^{9} \\
\text { Perniciosa anemia } \\
\text { Sjogren's syndrome } \\
\text { Crohn diseases }^{9}\end{array}$ \\
\hline Confirmed & $\begin{array}{l}\text { Patients with conditions } \\
\text { mild and severe }{ }^{10,11} \text { : } \\
\text { - Mucositis } \\
\text { - Glossitis } \\
\text { - Aphthous stomatitis } \\
\text { - Burning sensation } \\
\text { - Enanthema }\end{array}$ & \\
\hline
\end{tabular}

\section{Funding}

None.

\section{Conflict of Interest}

None declared.

\section{References}

1 World Health Organization. WHO COVID-19 : case definitions updated in public health surveillance for COVID-19. Available at: https://www.who.int/publications/i/item/WHO-2019nCoV-Surveillance_Case_Definition-2020. Accessed 2020

2 Riad A, Klugar M, Krsek M. COVID-19-related oral manifestations: early disease features? Oral Dis 2020. Doi:10.1111/ odi.13516

3 Cirillo N. COVID-19 outbreak: succinct advice for dentists and oral healthcare professionals. Clin Oral Investig 2020;24(7):2529-2535

4 Mujayanto R, Indraswary R. Differential diagnosis of COVID-19 enanthema. Eur J Dent 2020;14(S 01):S179-S181. Doi:10.1055/ s-0040-1719210

5 Falahchai M, Babaee Hemmati Y, Hasanzade M. Dental care management during the COVID-19 outbreak. Spec Care Dentist 2020;40(6):539-548

6 Santosh ABR, Muddana K. Viral infections of oral cavity. J Family Med Prim Care 2020;9(1):36-42

7 Clarkson E, Mashkoor F, Abdulateef S. Oral viral infections: diagnosis and management. Dent Clin North Am 2017;61(2):351-363

8 Porter SR, Scully C. Adverse drug reactions in the mouth. Clin Dermatol 2000;18(5):525-532

9 Rathee M, Jain P. Ageusia. StatPearls [Internet]. Treasure Island (FL): StatPearls Publishing. Published 2020. Available at: https://www.ncbi.nlm.nih.gov/books/NBK549775/. Accessed February 9, 2021 
10 Nuno-Gonzalez A, Martin-Carrillo P, Magaletsky K, et al. Prevalence of mucocutaneous manifestations in 666 patients with COVID-19 in a field hospital in Spain: oral and palmoplantar findings. Br J Dermatol 2021;184(1):184-185

11 Galván Casas C, Català A, Carretero Hernández G, et al. Classification of the cutaneous manifestations of COVID-19: a rapid prospective nationwide consensus study in Spain with 375 cases. Br J Dermatol 2020;183(1):71-77

12 Beran J, Špajdel M, Katzerová V, et al. Inosine pranobex significantly decreased the case-fatality rate among PCR positive elderly with SARS-CoV-2 at three nursing homes in the Czech Republic. Pathogens 2020;9(12):E1055

13 Srinivasan S, Torres AG, Ribas de Pouplana L. Inosine in biology and disease. Genes (Basel) 2021;12(4):600

14 Tobaiqy M, Qashqary M, Al-Dahery S, et al. Therapeutic management of patients with COVID-19: a systematic review. Infect Prev Pract 2020;2(3):100061
15 Tan Q Duan L, Ma Y, et al. Is oseltamivir suitable for fighting against COVID-19: In silico assessment, in vitro and retrospective study. Bioorg Chem 2020;104:104257

16 Holford P, Carr AC, Jovic TH, et al. Vitamin C-an adjunctive therapy for respiratory infection, sepsis and COVID-19. Nutrients 2020;12(12):E3760

17 Propper RE. Smell/taste alteration in COVID-19 may reflect zinc deficiency. J Clin Biochem Nutr 2021;68(1):3

18 Joachimiak MP. Zinc against COVID-19? Symptom surveillance and deficiency risk groups. PLoS Negl Trop Dis 2021;15(1):e0008895

19 Shakoor H, Feehan J, Mikkelsen K, et al. Be well: A potential role for vitamin B in COVID-19. Maturitas 2021;144:108-111

20 MIMS. Becom-Zet. Available at: https://www.mims.com/ indonesia/drug/info/becom-zet. Accessed April 1, 2021 